\title{
鉄の生物無機化学
}

\author{
三野芳紀
}

\section{Bioinorganic Chemistry of Iron}

\author{
Yoshiki Mino \\ Osaka University of Pharmaceutical Sciences; 4-20-1 Nasahara, Takatsuki, Osaka 569-1094, Japan.
}

(Received June 28, 2017)

\begin{abstract}
The X-ray crystallographic analysis of the single-crystal mugineic acid-Cu(II) complex showed that mugineic acid acts as a hexadentate ligand. Mugineic acid, a typical phytosiderophore, shows a marked stimulating effect on ${ }^{59} \mathrm{Fe}-u p-$ take and chlorophyll synthesis in rice plants. A salient feature is the higher reduction potential of the mugineic acid-Fe (III) complex than those of bacterial siderophores. X-ray diffraction study of the structurally analogous Co(III) complex of the mugineic acid-Fe(III) complex demonstrates that the azetidine nitrogen and secondary amine nitrogen, and both terminal carboxylate oxygens, coordinate as basal planar donors, and the hydroxyl oxygen and intermediate carboxylate oxygen bind as axial donors in a nearly octahedral configuration. The iron-transport mechanism in gramineous plants appears to involve the excretion of mugineic acid from the roots, which aids Fe(III)-solubilization and reduction of $\mathrm{Fe}$ (III) to $\mathrm{Fe}(\mathrm{II})$. Manganese peroxidase (MnP) is a component of the lignin degradation system of the basidiomycetous fungus, Phanerochaete chrysosporium. To elucidate the heme environment of this novel Mn(II)-dependent extracellular enzyme, we studied its ESR and resonance Raman spectroscopic properties. Consequently, it is most likely that the heme environment of MnP resembles that of cytochrome c peroxidase. In addition, degradation methods using basidiomycetous fungi or $\mathrm{Fe}^{3+}-\mathrm{H}_{2} \mathrm{O}_{2}$ mixed reagent were developed for dioxins and polychlorinated biphenyls. The complete amino acid sequences of respective $[2 \mathrm{Fe}-2 \mathrm{~S}]$ ferredoxins were determined and compared with those of other higher plants. Finally, the toxic effects of iron on human health and the development of novel antibacterial drugs capable of inhibiting the iron transport system of Vibrio vulnificus are described.
\end{abstract}

Key words_— mugineic acid; siderophore; ferredoxin; amino acid sequence; resonance Raman spectroscopy; manganese peroxidase

\section{1. はじめに}

筆者の研究生活を振り返つてみると，常に金属， いわゆる無機成分に関する研究に従事してきた。 大 阪薬科大学を昭和 47 年に卒業した後, 物理化学教 室の助手に就任し, 井上正敏先生の指導の下, 「グ リセロリン酸カルシウムに関する研究」をさせて頂 いた，徳島大学大学院では，下村 滋先生の指導の 下，「原子吸光法による植物中のゲルマニウムの分 析に関する研究」を行つた. 大学院修了後, 大阪薬 科大学生薬学教室の助手に就任し, 太田長世先生と ともに, 蛍光 $\mathrm{X}$ 線分析装置を用いて, 各種生薬中 に含まれる無機元素の分析を中心に研究を進めてき た. 一方では, 京都大学薬学部の杉浦幸雄先生との

大阪薬科大学 (T569-1094 大阪府高梘市奈佐原 4-20-1) e-mail:ymino@gaps.oups.ac.jp

本総説は, 平成 28 年度退職にあたり在職中の業績を中 心に記述されたものである。
共同研究で「植物の鉄取り込みに関する研究」を進 めて行き, このテーマで薬学博士の学位を取得し た．その後も，いろいろな方面で鉄に関する研究を 進めてきたので, 本総説では,「鉄の生物無機化学」 の題目で筆者が研究してきた内容を中心にまとめて みたい。

鉄は必須金属の1つである。「なぜ，鉄が必須金 属になったか?」と学生たちに尋ねると,「へモグ ロビンなどのタンパク質に含まれているから」と答 える，もちろん，この答で間違ってはいないが，筆 者は，あえて満点は与えず，「生命が地球上に誕生 したときの周りの環境に鉄分が豊富にあった。特に,

2 価鉄のイオンとして溶けており，生命体はその鉄 を利用して，進化を遂げてきたから」そして，「そ の鉄を重要な生命反応の一員として，利用するよう になったから」と答えさせている.

鉄は，有機化合物では難しい反応を容易に行える 
特技を持つている，その特技とは，酸化還元反応で あり，もう 1 つは酸素分子に親和性を持つというこ とである．鉄は 2 価と 3 価の状態をとるので，電子 の移動を伴う酸化還元反応を得意とする（銅は 1 価 と 2 価の状態をとるので鉄同様酸化還元酵素に含ま れるが， 2 価の状態しかとらない亜鉛は縮合や加水 分解反応を担う酵素に含まれる)。シトクロム類, 鉄一硫黄タンパク質は，電子伝達系に関与する。 ま た，2 価鉄は酸素分子との親和性が高く，へモグロ ビン中の鉄が酸素分子と結合するのも，この性質に 由来する．このように多くのタンパク質や酵素に鉄 原子が利用されているが，実は，生物が鉄を利用す るのは容易ではなく，多くの生物は常に鉄欠乏の状 態にある.1,2) これは，30 億年前に起こった地球上 の大気環境の変化に起因している. 海洋においてラ ン藻類の先祖に当たる, 光合成を行うシアノバクテ リアが大増殖を遂げたのである，彼らは光合成の副 産物として酸素を環境に放出し始めた. 最初に海洋 中の比較的可溶性の 2 価鉄を 3 価に酸化した。 その 結果 3 価鉄は, 不溶性の水酸化鉄として, 海底に沈 降していった。時を経て，それは赤色の酸化鉄 （III）に変化していく，これらは数億年後海底の隆 起によって地上に現れ，これらを含む赤鉄鉱は近代 文明の礎となった（オーストラリアの大地の色は赤 鉄鉱を含むため赤褐色)，海洋中の 2 価鉄を酸化し 終えた酸素は，大気中に放出され，大気の成分を今 とほとんど同じ酸素濃度（約 20\%）に変えていっ た．そして，地球上は酸素の溢れる酸化状態になつ ていった. このような大気に接する水中では鉄は 3 価として存在するので, 不溶性の状態で存在し, 生 物がそれを利用するにはあまりにも低い濃度でしか 溶けていない。 そのような理由により，多くの生物 (微生物) は絶滅したと考えられる。しかしながら, 一部の生物は突然変異を繰り返すことで，不溶性の 鉄を溶かして，体内に取り込むという素晴らしい技 を手に入れた。このとき, 微生物が鉄欠乏状態で鉄 を溶かすために分泌される，3 価鉄に親和性の高い キレーターがシデロホア（鉄イオン運搬体）であ る. ${ }^{1-3)}$ 大気と接する環境に生育する微生物はこの ようなシデロホアを介する独自の鉄取り込み機構を 備えている. Figure 1 は, 微生物の鉄取り込夕機構 をポンチ絵的に示したものである. 飛行機から何者 かが放たれたが，間近で見ると，S $\mathrm{S}$ のークのへル

メットをかぶり，カニの爪のような腕を持ってい る。「カニの爪」はギリシャ語で chele で，多座配 位子による金属イオンへの配位を意味する chelate の語源である。したがって，この者はキレーターで あり, S のマークは Superman ではなく Siderophore (sidero: 鉄, phore: 運搬体) の頭文字である. すなわち，飛行機に見立てた微生物が鉄を取り込む ために菌体外にシデロホアを分泌しているところを 示している.このような取り込夕機構は, 他の必須 金属の場合にはみられない。微生物の鉄取り込みは Neiland らによる精力的な研究により有用な知見が 得られており，分子レベルでの考察が可能になって きた. ${ }^{4,5)}$ 一方，植物の鉄取り込みはほとんど分かつ ていなかった．筆者は，幸運にも，植物の鉄取り込 みに関する研究を行う機会を得た。そこで，2.で は，植物の鉄取り込み機構について説明したい。こ のテーマで学位を取得後, 米国に留学し Oregon Graduate Center (Portland, Oregon) にて，共鳴ラ マン分光法による鉄含有タンパク質の研究を行う機 会を得た。 3.では，リグニン分解酵素の一種であ るマンガンペルオキシダーゼと，それをヒントに帰 国後に行つたダイオキシンの分解に関する研究を簡 単に述べる. 4. では，共鳴ラマン分光法で検討し たフェレドキシンなどの鉄-硫黄タンパク質につい て紹介する．5.では，フェレドキシンの研究をヒ ントに, 帰国後研究を開始したフェレドキシンの一 次構造を利用する植物の分類法と同定法について述 べる．6.では，生体に必須である鉄の“もろ刃の 剣”の一面，すなわち毒作用について述べたい。最 後に 7. では, 病原菌の鉄獲得系を阻害することで 抗菌活性を示す化合物の探索について述べる.

地球が誕生して約 45 億年, 生命が発生してから でも 35 億年の長い年月がたっている。その間，生

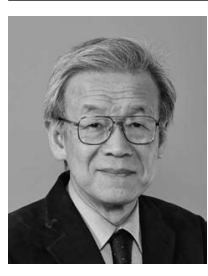

三野芳紀
香川県出身. 1972 年大阪薬科大学卒業 後, 同大学助手. 1977 年徳島大学大学 院修士課程修了後, 大阪薬科大学助 手，講師，助教授を経て，2006 年環境 分析学研究室教授. この間, 77 年京都 大学薬学部研修員（放射性薬品化学講 座), 84 年薬学博士 (京都大学), 8687 年まで米国 Oregon Graduate Center (Bioinorganic Chemistry) 留学. 2010 年大阪薬科大学薬品分析化学教授. 2017 年 3 月大阪薬科大学定年退職. 大 阪薬科大学名誉教授. 

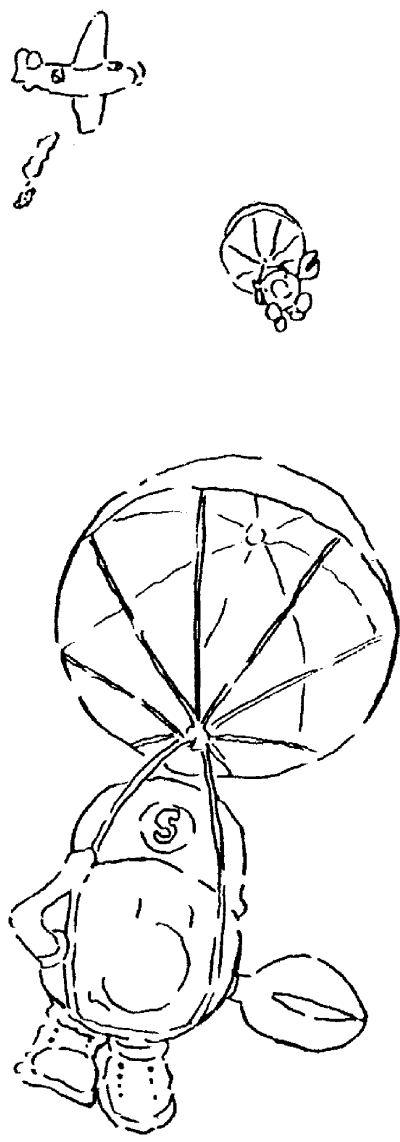

Fig. 1. Siderophore Secreted from a Microorganism (Airplane)

Modified illustration based on Vision from Oregon Graduate Center, 3, 11-12 (1987).

命は地球という無機環境にさらされてきた。した がつて無機環境に存在する 100 種ほどの元素の有用 性を試してみるには十分な時間があった。生物は自 らのいのちをよりよく存続させるために貪欲なもの である. 100 種ほどの元素の中からおよそその 3 分 の 1 に当たる 30 種ほどの元素の有用性を認めて, それらを利用してきた。いった利用しだすと，そ れらに依存性ができて，それらの元素は生物にとつ て必須となる，ここでは，ほとんどすべての生物に 必須で，様々な機能を果たしている鉄を取り上げ, いのちとの係わりについて考えてみたい. 生物が鉄 を取り込むため，どのように巧妙な手段を発展させ てきたのか，また体内に取り込まれた鉄はどのよう な構造の分子として存在し，いかなる機能を果たし ているのか，そして，このような生体に不可欠な鉄 含有分子が，逆に生体に障害作用を及ぼす可能性に ついても紹介できれば幸いである.
2. ムギネ酸一鉄錯体と植物の鉄取り込み機構一 歪みの少ない八面体構造を形成．動物に対する生理 活性にも興味一

鉄は，好気性条件下では 3 価イオンとして存在 し，中性付近の $\mathrm{pH}$ において極めて難溶性の水酸化 鉄（III）を形成する。この不溶性の必須金属を利 用するために，微生物はシデロホアと呼ばれる強力 な鉄キレーター（その構造からヒドロキサム酸型と カテコール型に大別される）を分泌することが知ら れている (Figs. 2 and 3).2,3)

植物もまた，正常な成長を維持するために，絶え ず鉄の供給を必要としている。もし，鉄欠乏状態に なれば，クロロフィルの生合成が抑制され，葉が黄 変する鉄クロロシス（萎黄病）が起こってくる．普 通，土畩それ自体が鉄欠乏になることはないが，ア ルカリ土袞 [水酸化物イオンのため不溶性の水酸化 鉄（III）が生成し易い）の多くでは利用可能な鉄 イオンが不足する場合がある. ${ }^{6}$ しかし，アルカリ 土壌に生育する植物すべての植物が鉄クロロシスを 起こすのではなく，そのうちの多くの植物は不溶性 の鉄を効率よく吸収することが可能である．鉄欠乏 耐性と呼ばれるこの種の植物は鉄ストレス（鉄欠乏 による圧力）に対して，(1)根からの水素イオンの放 出, (2)根からの還元剂の放出, (3)根における鉄 （III）の還元，(4)根における有機酸の増加などの適 応機構を持っていることが, Brown によって示さ

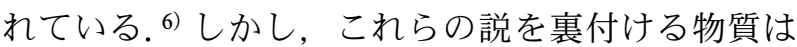
まだ同定されておらず，また，筆者が研究を始める までは，植物界のシデロホアも見い出されていな かった。

筆者の研究によって，イネ科植物の鉄取り込みが ムギネ酸と呼ぶ新アミノ酸を介して，行われている ことが示され，注目を集めてきた。このアミノ酸の 発見は，高城が行った鉄欠乏耐性のエンバク (燕麦) と非耐性であるイネの水耕実験に始まった，彼はこ の実験の過程で，中性付近の $\mathrm{pH}$ で鉄溶解能を持つ 物質がイネの根からほとんど分泌されないのに対 し，エンバクの根から多量に分泌されること，さら にその分泌量が鉄欠乏時に著しく増加することを見 い出した.7)ついで，竹本らは，鉄欠乏耐性の大麦 (Hordeum vulgare L. var. Minorimugi) の根の洗液 から，ムギネ酸と命名された新アミノ酸を単離し, 微生物シデロホアとは全く異なる，そのユニークな 


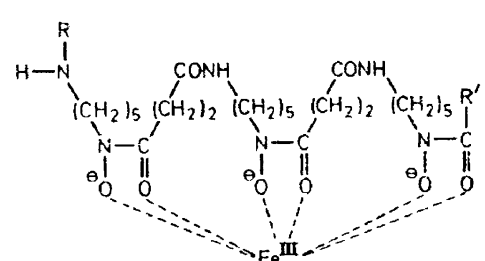

Ferrioxamine $\mathrm{B}$ $\left(\mathrm{R}=\mathrm{H}, \mathrm{R}^{\prime}=\mathrm{CH}_{3}\right)$

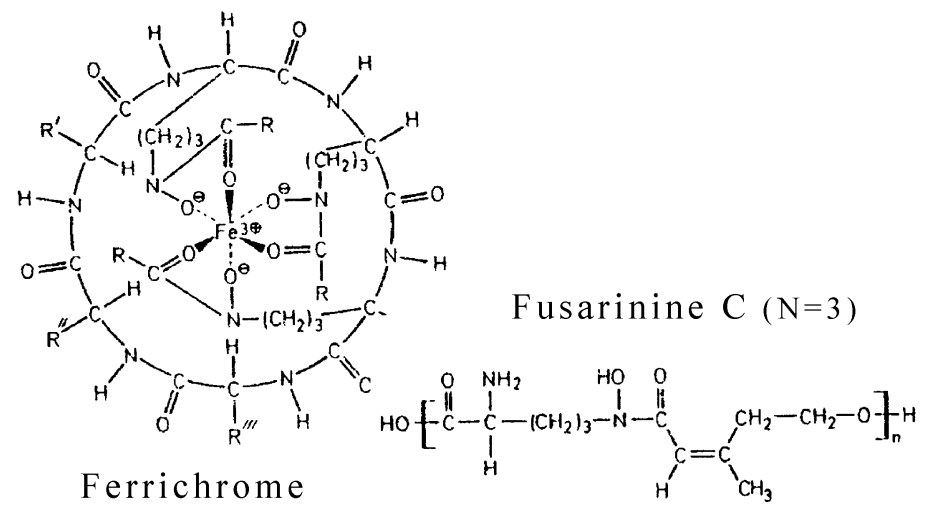

$\left(\mathrm{R}=\mathrm{CH}_{3}, \mathrm{R}^{\prime}=\mathrm{R},{ }^{\prime}=\mathrm{R},{ }^{\prime},=\mathrm{H}\right)$

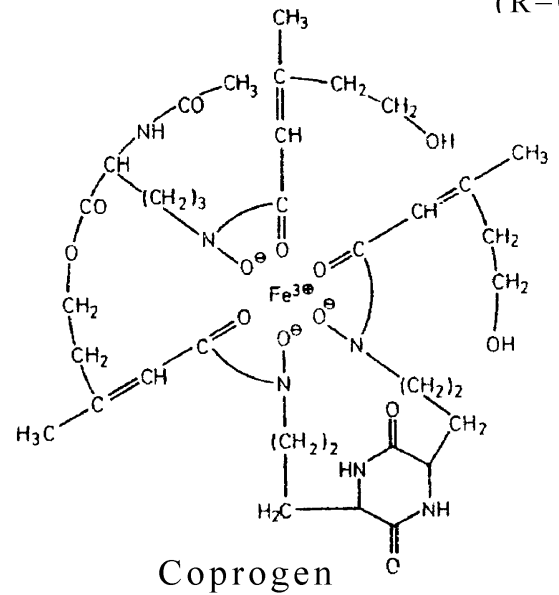

Coprogen

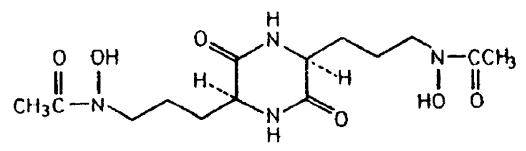

Rhodototulic acid

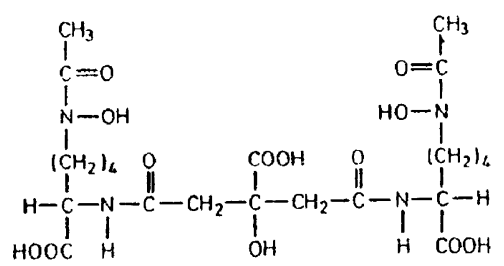

Aerobactin

Fig. 2. Hydroxamic Acid Siderophores
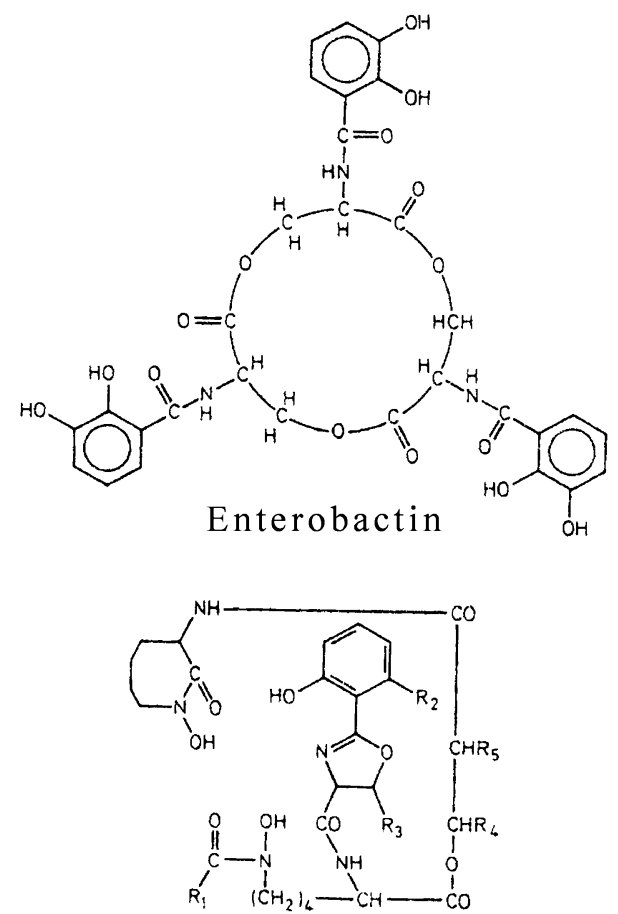

Mycobactin

$\left(\mathrm{R}_{1}=\mathrm{C}_{\mathrm{n}} \mathrm{H}_{\mathrm{m}}, \mathrm{R}_{2}=\mathrm{R}_{3}=\mathrm{CH}_{3}, \mathrm{R}_{4}=\mathrm{C}_{2} \mathrm{H}_{5}, \mathrm{n} \geqq 12\right.$ )
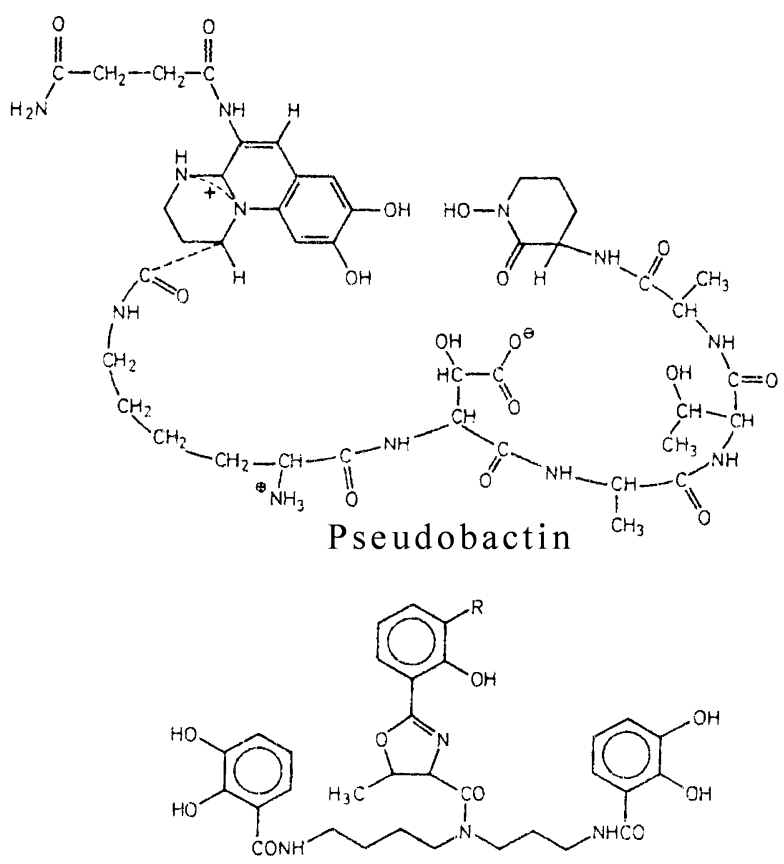

Agrobactin $\left(\mathrm{R}=\mathrm{CH}_{3}\right)$

Parabactin $(\mathrm{R}=\mathrm{H})$

Fig. 3. Catechol-Containing and Mixed Ligand Siderophores 


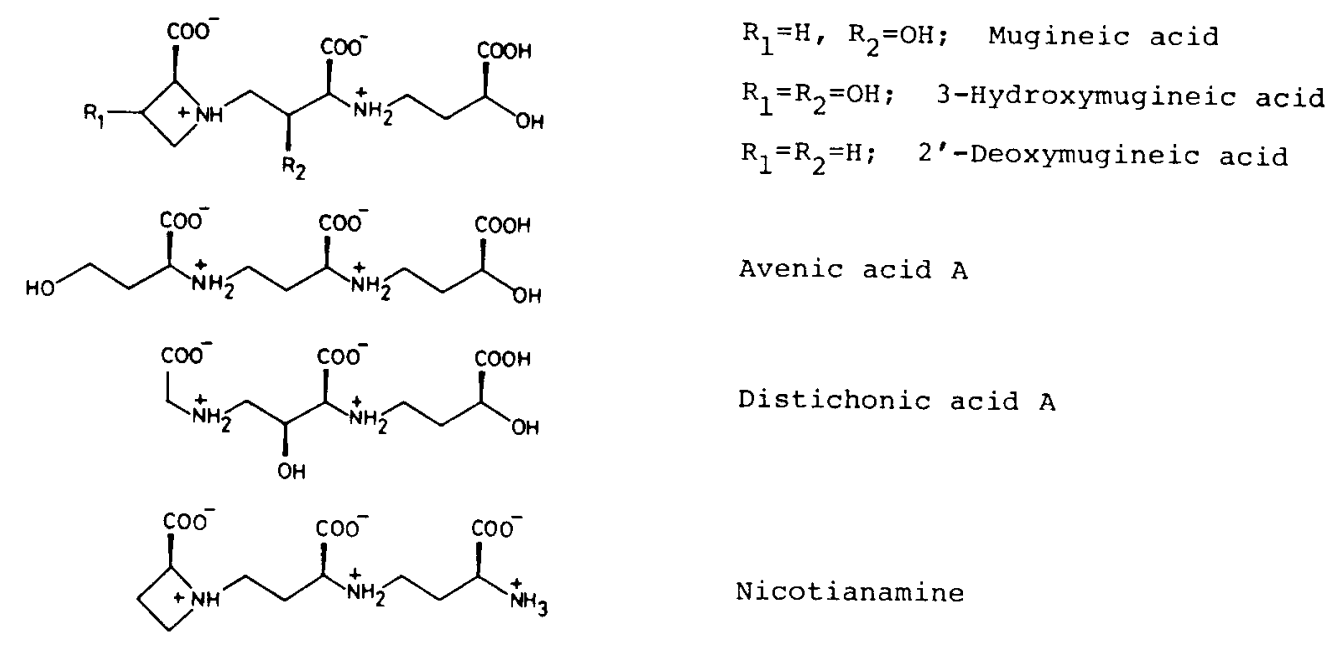

Fig. 4. Iron Chelators of Plant Origin
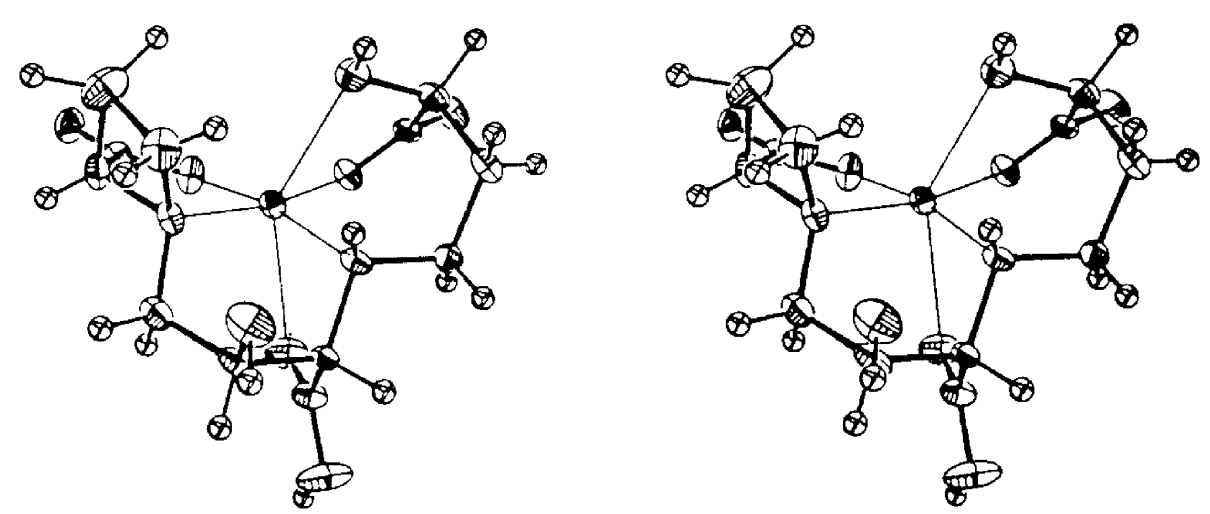

Fig. 5. Stereoscopic Drawing of the Mugineic Acid-Cu(II) Complex
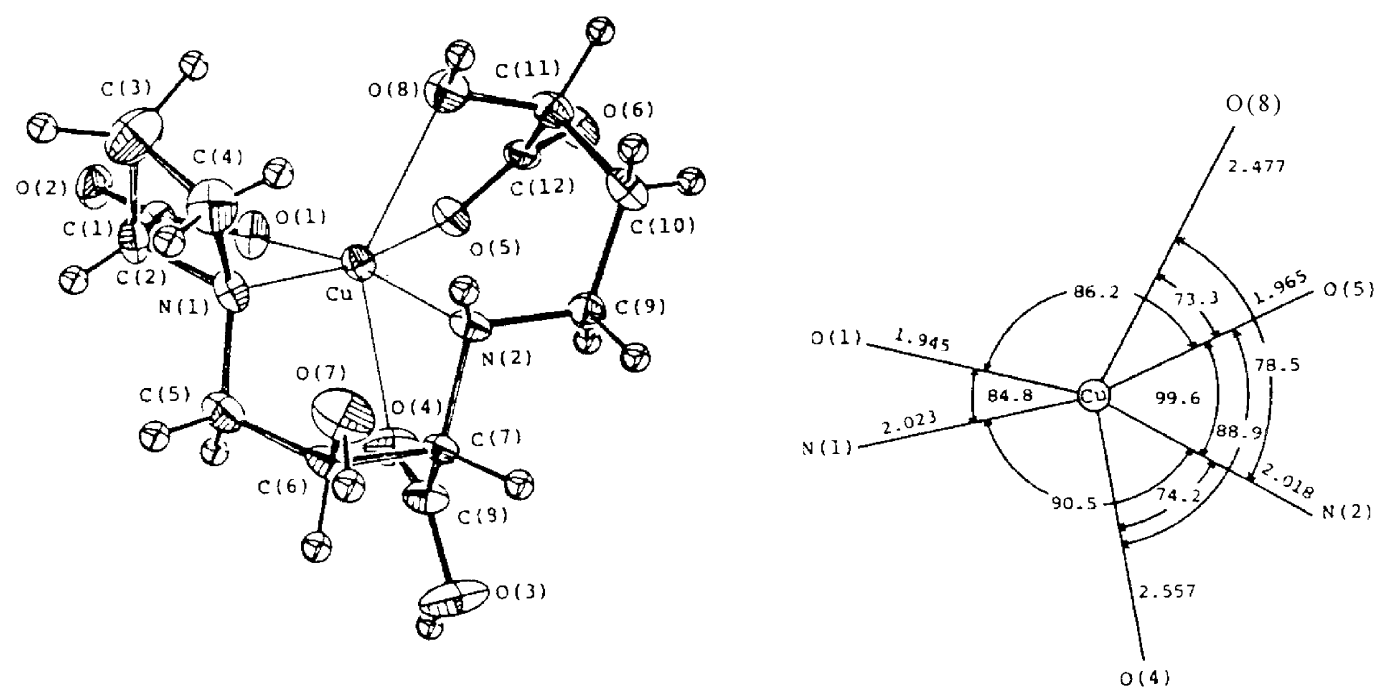

Fig. 6. Bond Lengths and Angles of the $\mathrm{Cu}$ (II) Coordination Site in the Mugineic Acid-Cu(II) Complex 


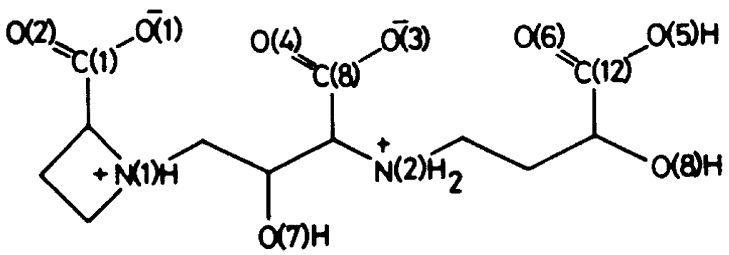

Mugineic acid

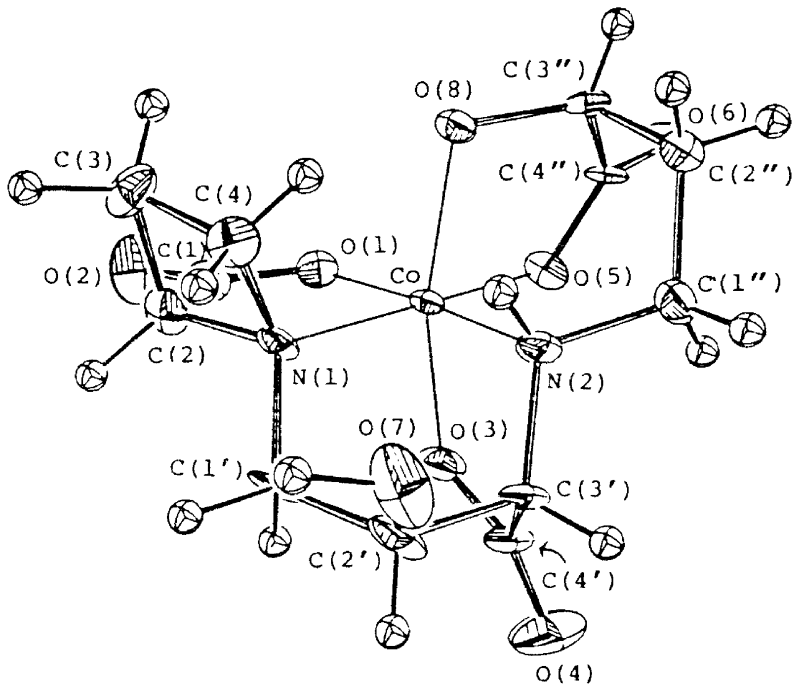

Fig. 7. A Perspective Drawing of the Mugineic Acid-Co (III) Complex

構造を解明した（Fig. 4). ${ }^{8}$ そ後，大麦以外のイ ネ科植物からムギネ酸様活性物質が次々と単離され ており, 9)これらのアミノ酸がイネ科植物の鉄の吸 収と移動に重要な役割を果たしていることが推定さ れた。

筆者は，植物界のシデロホアと考えられるムギネ 酸の鉄錯体の構造と性質を明らかにする目的で種々 検討を重ね，イネ科植物の鉄取り込み機構に関して 有力な知見を得ることができたので，以下に紹介す る.

筆者の最大の関心は，低分子（分子量 320）で, しかも鎖状のムギネ酸分子が鉄（III）などの金属 イオンとどのような構造の錯体を形成するかにあっ た。そこでムギネ酸の安定な金属錯体の 1 つである 銅（II）錯体の結晶解析を試みた結果，ムギネ酸が 銅（II）イオンに六座配位子として機能し，1 分子 で歪んだ八面体構造を有することを明らかにした. そのとき，筆者は植物の分子設計の巧みさに驚かず にはいられなかった（Figs. 5 and 6).10,11) なぜな ら，今までX 線結晶解析で明らかにされた多くの アミノ酸及びペプチドの銅（II）錯体において，六

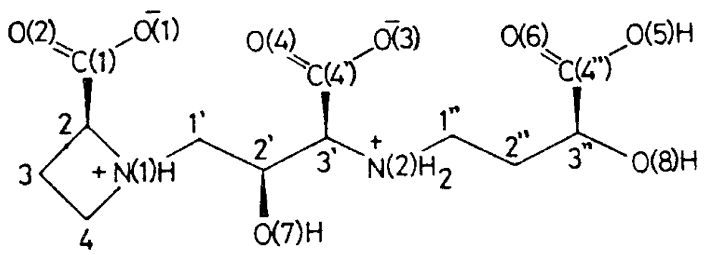
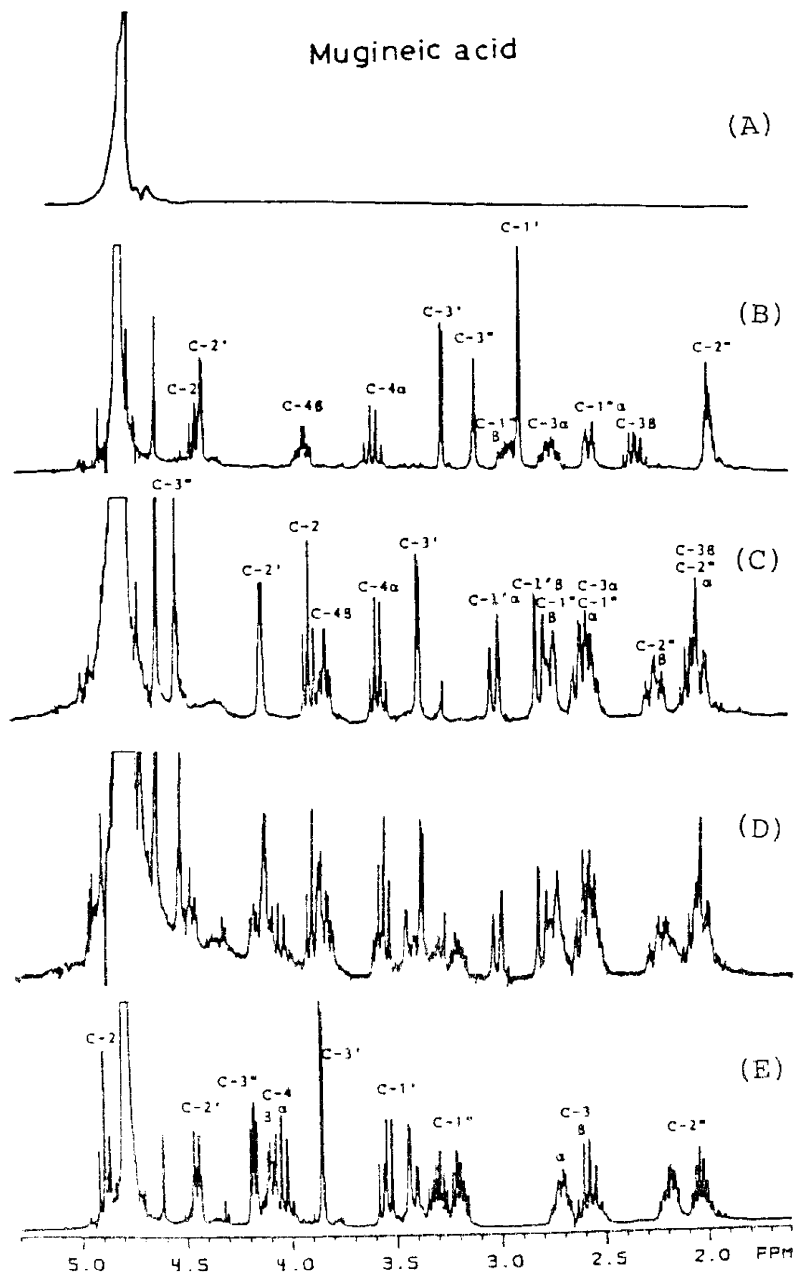

Fig. 8. $\quad 360 \mathrm{MHz}$ FT- ${ }^{1} \mathrm{H}$ NMR Spectra of $1: 1$ Mugineic Acid-Fe(III) Complex (A), $1: 1$ Mugineic Acid-Co(III) Complex (B), 1:1 Mugineic Acid-Zn(II) Complex (C), 2: 1 Mugineic Acid-Zn (II) Complex (D), and Ligand Only (E) at $\mathrm{pD} 4.5$

座配位子として機能する例は皆無だったからであ る. 銅（II）錯体に引き続いて，鉄（III）錯体と構 造上類似性を有するコバルト（III）錯体の結晶解 析及びNMR による溶液中のコンフォメーション解 析を行い，より歪みの少ない八面体構造をとること が明らかとなった（Figs. 7 and 8).12-15) また，鉄 （III）錯体に関しても，電位差滴定，電子スピン共 鳴などの結果から，コバルト（III）錯体に類似の 構造であることが確認できた。ムギネ酸の金属錯体 において，中間にあるアルコール性水酸基以外のす 


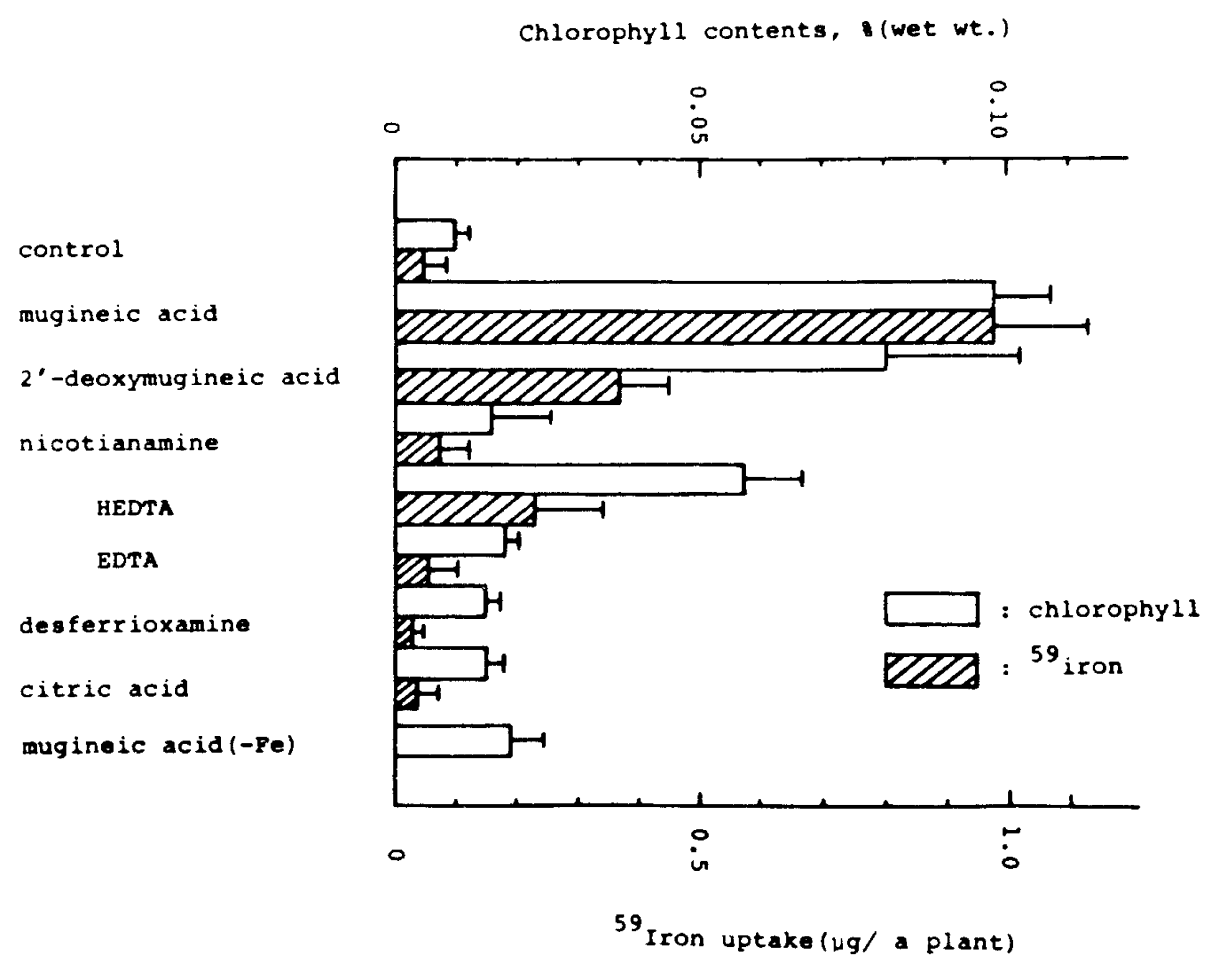

Fig. 9. Effect of Some Chelators on Iron-uptake and Chlorophyll Synthesis in a Water-cultured Rice Plant

Table 1. Iron-solubilizing Abilities of Mugineic Acid and Related Compounds

\begin{tabular}{|c|c|c|c|c|c|c|c|}
\hline \multirow[b]{2}{*}{ Chelators } & \multicolumn{7}{|c|}{ Iron concentration $(\mathrm{ppm})$ of filtered solutions } \\
\hline & $\begin{array}{l}\text { Buffer } \\
\text { alone }\end{array}$ & $\begin{array}{c}+ \text { All } \\
\text { nutrients }\end{array}$ & $\begin{array}{c}+\mathrm{CaCl}_{2} \\
(0.5 \mathrm{mM})\end{array}$ & $\begin{array}{l}+\mathrm{MgSO}_{4} \\
(0.8 \mathrm{mM})\end{array}$ & $\begin{array}{c}+\mathrm{NaH}_{2} \mathrm{PO}_{4} \\
\quad(0.5 \mathrm{mM})\end{array}$ & $\begin{array}{c}\text { Three } \\
\text { nutrients }\end{array}$ & Other \\
\hline Control & $<0.3$ & $<0.3$ & $<0.3$ & $<0.3$ & $<0.3$ & $<0.3$ & $<0.3$ \\
\hline Mugineic acid & 3.9 & 2.0 & 3.0 & 2.9 & 3.0 & 2.3 & 3.0 \\
\hline $2^{\prime}$-Deoxymugineic acid & 3.7 & 1.6 & a & a & a & a & a \\
\hline Nicotianamine & 0.4 & $<0.3$ & $<0.3$ & $<0.3$ & $<0.3$ & $<0.3$ & $<0.3$ \\
\hline HEDTA & 4.8 & $<0.3$ & 0.5 & 1.3 & 3.1 & $<0.3$ & 4.7 \\
\hline EDTA & 7.5 & $<0.3$ & $<0.3$ & 0.4 & 3.3 & $<0.3$ & 6.0 \\
\hline Desferrioxamine & 9.3 & 7.9 & 8.1 & 8.2 & 8.4 & 7.9 & 9.3 \\
\hline Citric acid & 0.4 & $<0.3$ & $<0.3$ & $<0.3$ & $<0.3$ & $<0.3$ & $<0.3$ \\
\hline
\end{tabular}

${ }^{a}$ Experiment not performed.

ベての官能基が金属イオンへの配位に関与していた が，事実，この水酸基 $\mathrm{O}(7) \mathrm{H}$ の欠如したデオキシ 型とアゼチジン環の C (3)-C (4)の欠如したグリシ ン型のムギネ酸様活性物質 ( $2^{\prime}$-deoxymugineic acid と distichonic acid A）が小麦とビール麦からそれ ぞれ単離されている（Fig. 4).

ムギネ酸の生理活性で特筆すべきことは，水耕栽 培中のイネの培養液に, エチレンジアミン四酢酸 (ethylenediaminetetraacetic acid; EDTA) などの合 成キレート剂あるいは微生物由来のシデロホアの 1
種であるデスフェリオキサミン（Fig. 2 の ferrioxamine B から鉄を除いた構造, desferrioxamine; DF) を添加してもイネの鉄取り込みは増加しないのに対 し，ムギネ酸を始めとする植物由来のキレーターは 顕著に鉄取り込みを促進し，その結果として植物の 鉄クロロシスを改善できる点である（Fig. 9)。当 然, EDTA とDF は中性溶液中で鉄を溶解でき, その程度はそれらの鉄（III）錯体の安定度定数 （EDTA 25.1，DF 30.6）からムギネ酸の溶解能力 を上回ると推定される，事実，緩衝液のみを含む溶 
Table 2. Reduction Potentials of Some Iron Transport Compounds

\begin{tabular}{|c|c|}
\hline Complex & $\mathrm{E}(\mathrm{pH} 7.0) v s . \mathrm{NHE}, \mathrm{mV}$ \\
\hline Mugineic acid-Fe (III) & -102 \\
\hline Nicotianamine-Fe (III) & -181 \\
\hline Ferric aerobactin & -336 \\
\hline Ferric rhodotorulic acid & -359 \\
\hline Ferrichrome A & -448 \\
\hline Ferrioxamine B & -468 \\
\hline Ferric enterobactin & $\sim-750$ \\
\hline
\end{tabular}

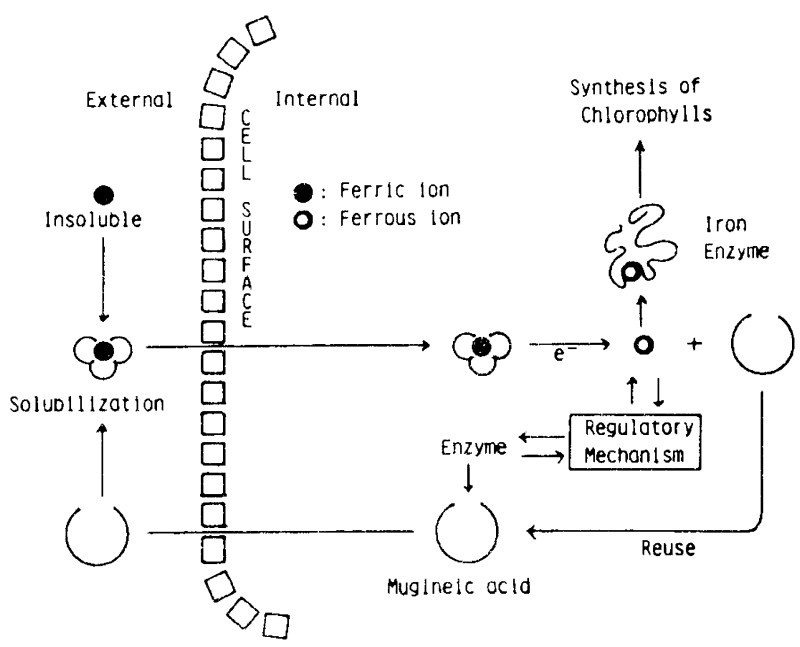

Fig. 10. Proposed Mechanism for Iron Transport in Gramineous Plants
液中での鉄溶解能は，DF $>$ EDTA $>$ ムギネ酸の順 で大きいという結果が得られた（Table 1, buffer alone)。しかし，栄養素を含む培養液中でのそれは， DF>ムギネ酸》EDTA であった（Table 1, all nutrients)。したがって，自然界においては，ムギ ネ酸の方が鉄を選択的に溶解する能力においても EDTA より優れていると言える。，一方，最も大き な鉄溶解能を有する DF に鉄取り込み促進作用がみ られないのは，その鉄錯体が根の生体膜をうまく通 過できないためと思われる。この点に関して，今ま でに単離されたムギネ酸様活性物質が 6 個の配位基 を有し非常に類似した構造であるという事実も興味 深い.

さて，このようにムギネ酸-鉄（III）錯体の種々 の性質が明らかになったが，特に注目すべき点は, ムギネ酸-鉄（III）錯体が安定（安定度定数 18.1） であるのに対し，鉄（II）錯体は不安定（8.1）で あること，及び鉄（III）錯体の還元電位が生体内 の還元剂［例えば NAD (P) H］によって容易に還 元され得るような高い值（-102 mV vs. NHE）を 示す点である（Table 2)。これらの結果から，イネ 科植物の鉄取り込み機構は，次のように考えられ る; (1)根からムギネ酸を分泌し錯形成によって土壌 中の鉄を可溶化し，体内に取り込む，(2)その錯体を 適当な部位に輸送した後，不安定な鉄（II）錯体へ 還元しクロロフィル合成に必要な酵素などに引き渡

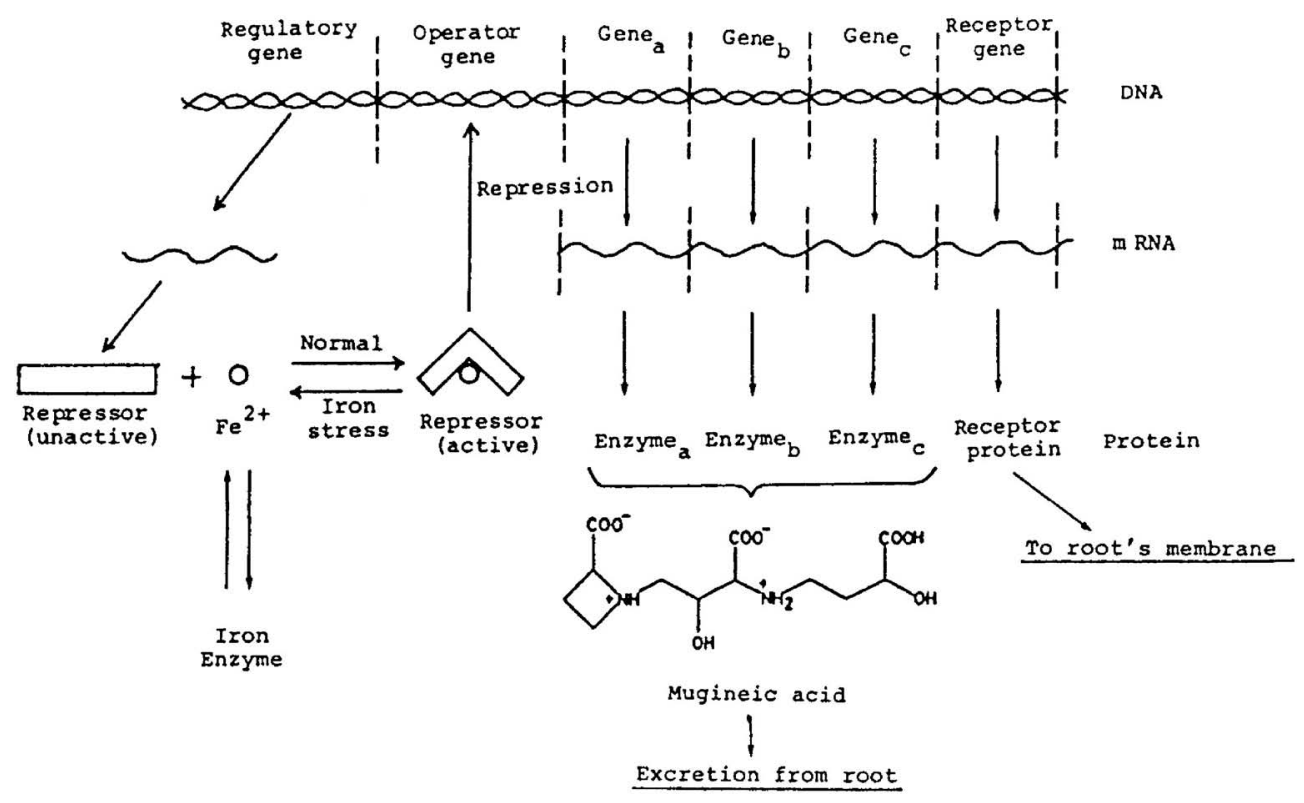

Fig. 11. Regulatory Mechanism (Hypothesis) 
MA: mugineic acid

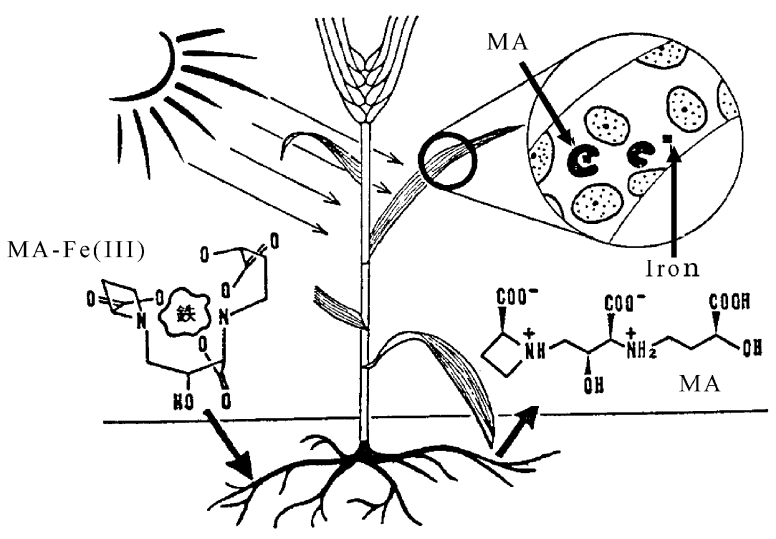

Fig. 12. Modified Illustration Based on Asahi Newspaper, October 1,1986

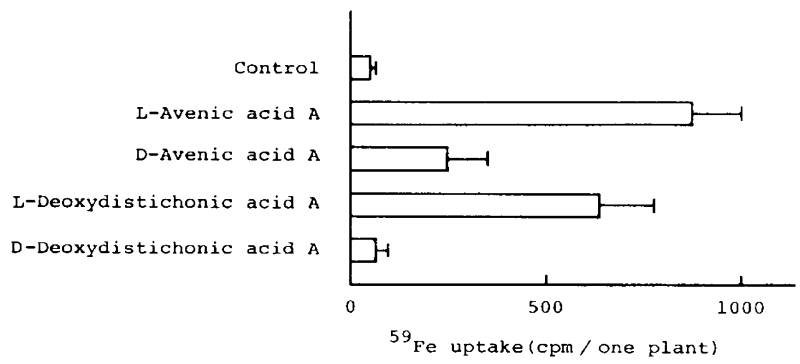

Fig. 13. Effects of Optical Isomers of Phytosiderophores on Iron-uptake in a Water-cultured Rice Plant

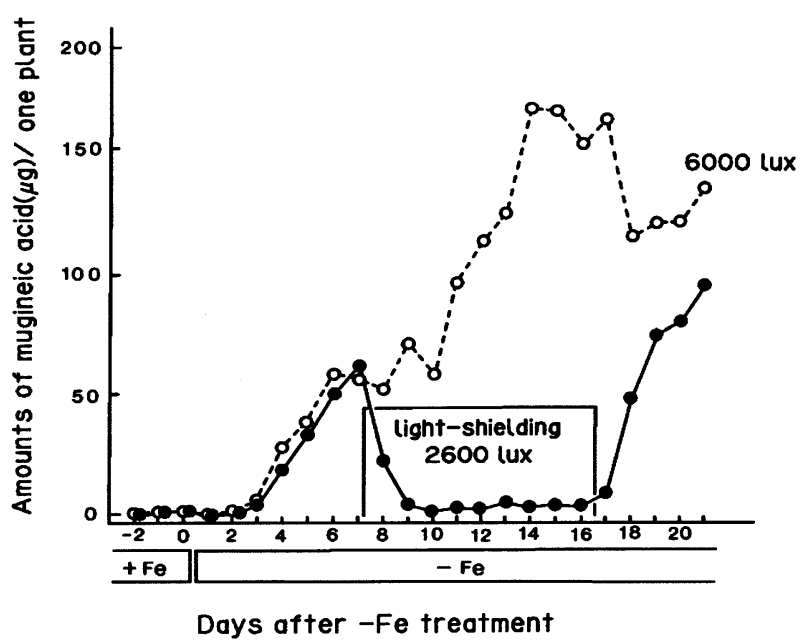

Fig. 14. Effects of Light on the Amounts of Mugineic Acid Secreted from Barley Roots

O: 6000 lux, $0: 2600$ lux for the period from 7 to $16 \mathrm{~d}$ after - Fe treatment and 6000 lux for the other periods.

す，(3)フリになったムギネ酸は再利用あるいは代 謝される（Figs. 10-12）。実際，ある種の微生物に おいても類似の機構で鉄を取り込み，利用すること が知られている. 1,2) また，筆者は構造特異的な鉄取

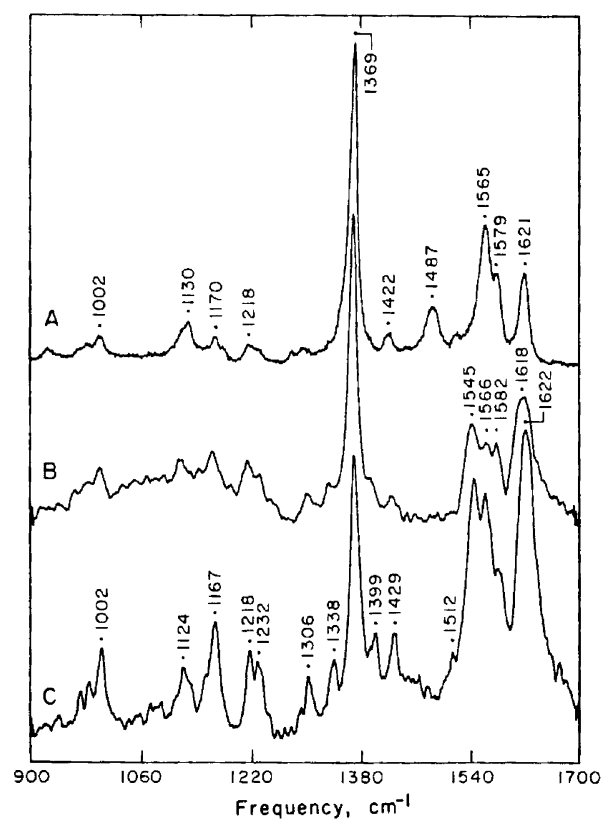

Fig. 15. Resonance Raman Spectra of Native Manganese Peroxidase

A, 413.1-nm excitation; B, 488.0-nm excitation; C, 514.5-nm excitation.
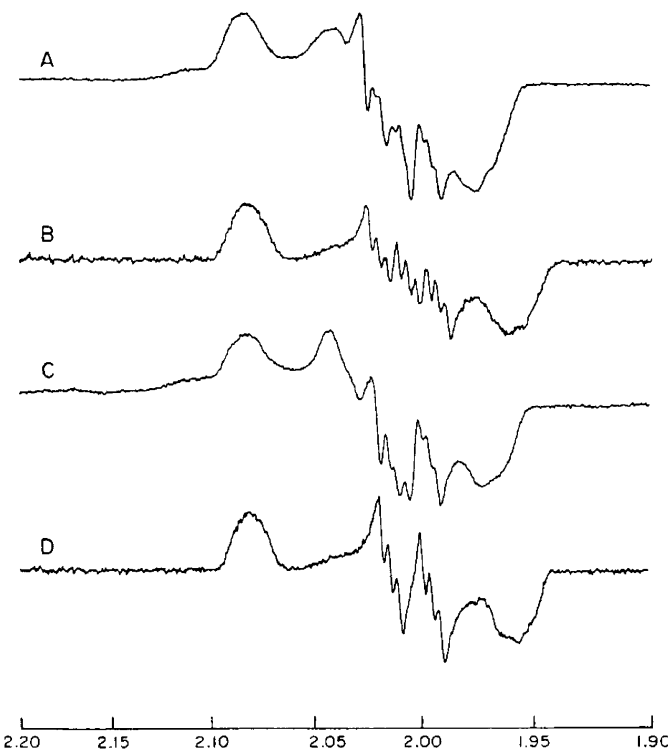

Fig. 16. ESR Spectra of the ${ }^{14} \mathrm{NO}-$ and ${ }^{15} \mathrm{NO}-$ Adducts of Ferrous Manganese Peroxidase and Ferrous Horseradish Peroxidase

A, ${ }^{14} \mathrm{NO}-\mathrm{MnP} ; \mathrm{B},{ }^{14} \mathrm{NO}-\mathrm{HRP} ; \mathrm{C},{ }^{15} \mathrm{NO}-\mathrm{MnP} ; \mathrm{D},{ }^{15} \mathrm{NO}-\mathrm{HRP}$. All spectra recorded at $\sim 14 \mathrm{~K}$.

り込み機構が植物にも存在することを，ムギネ酸様 活性物質 (avenic acid A と deoxydistichonic acid A) のエナンチオマーを使った ${ }^{59} \mathrm{Fe}$ 取り込み実験から 明らかにした（Fig. 13）.16) さらに，大麦根からの ムギネ酸分泌と光（照度）の関連についても興味深 い知見を得た (Fig. 14).2,17) すなわち，ムギネ酸の 


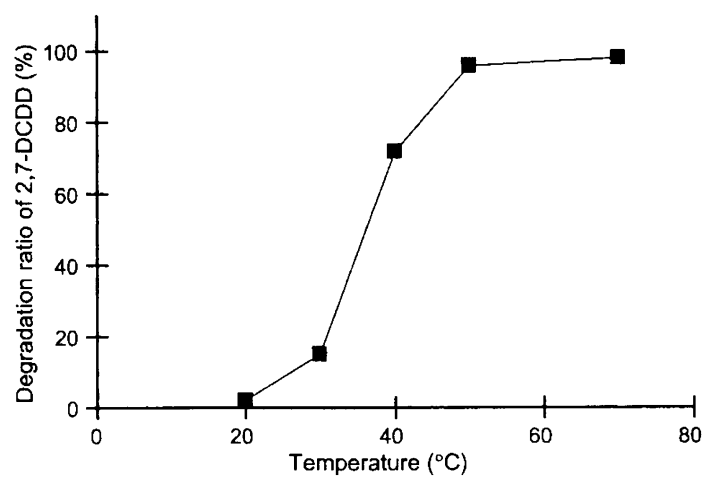

Fig. 17. Effects of Temperature on the Degradation of 2,7Dichlorodibenzo- $p$-dioxin (DCDD)

DCDD $(5 \mu \mathrm{g} / \mathrm{mL})$ was incubated in $\mathrm{Fe}^{3+}(8 \mathrm{~mm})-\mathrm{H}_{2} \mathrm{O}_{2}$ (1\%) mixed reagent for $15 \mathrm{~min}$ at $50^{\circ} \mathrm{C}$, unless otherwise noted.

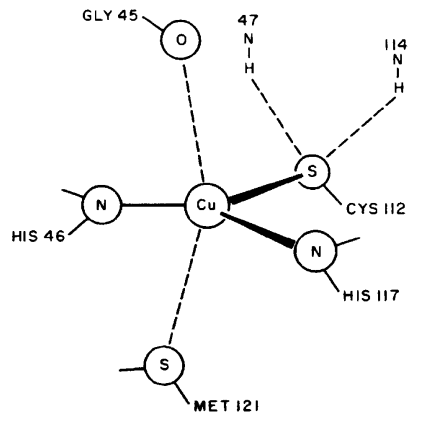

Fig. 18. Blue Copper Center of Azurin from Alcaligenes denitrificans

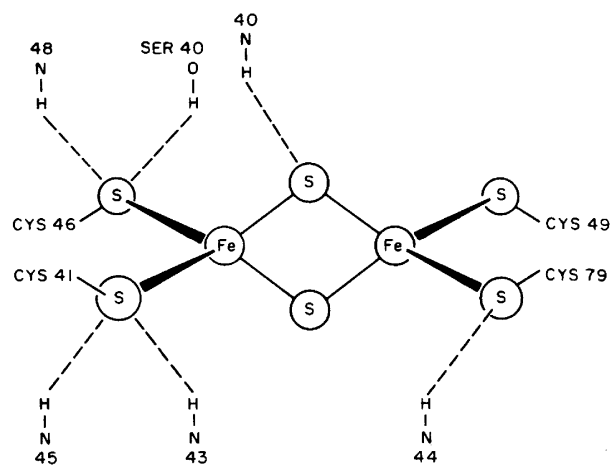

Fig. 19. Binuclear Iron-Sulfur Cluster of Ferredoxin from Spirulina platensis

分泌量は，大麦が前日に受けた光量（日照）に主に 依存することなどが分かった．現在のところ，ムギ ネ酸様活性物質の検出はイネ科植物に限られるが, 他の植物においても同様の機構で鉄取り込みがなさ れている可能性は否定できない。

世界の陸地の 25-30\%はアルカリ土壌であると言 われていることから，植物の鉄欠乏症は世界的に重 要な問題である.イネ科植物の中でも特に食料とし

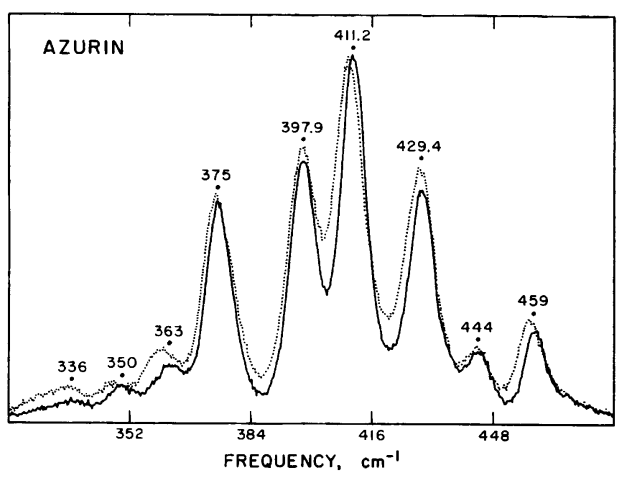

Fig. 20. Resonance Raman Spectra of Alcaligenes denitrificans Azurin in $\mathrm{H}_{2} \mathrm{O}(-)$ and $\mathrm{D}_{2} \mathrm{O}(\cdots)$

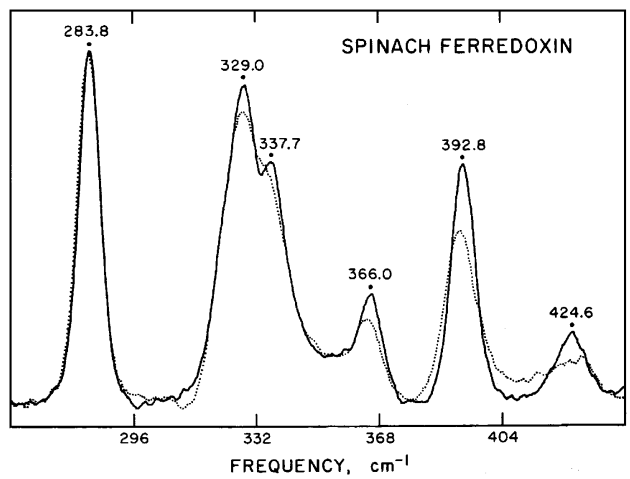

Fig. 21. Resonance Raman Spectra of Oxidized Spinach Ferredoxin in $\mathrm{H}_{2} \mathrm{O}(-)$ and $\mathrm{D}_{2} \mathrm{O}(-\cdot)$

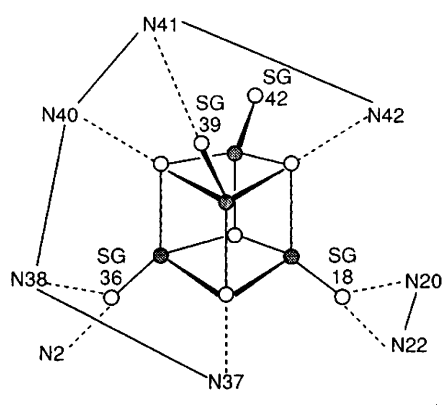

$\mathrm{Fd}_{\mathrm{ox}}$ Cluster II

Fig. 22. Schematic Drawing of Cluster II of Peptococcus aerogenes

Iron atoms $(\bullet)$, sulfur atoms $(\bigcirc)$, and hydrogen bonds $(\cdots)$.

て重要なイネ, トウモロコシなどが鉄欠乏非耐性で あることを考え合わせると，ムギネ酸が将来，鉄ク ロロシス改善剤として広く利用される可能性は大き い. 実際，ムギネ酸合成酵素の遺伝子を組み込んだ イネが開発され，実用化されつつある. ${ }^{18)}$ また，微 生物由来のシデロホアが医薬品（鉄排泄剂）になり 得たように，植物界のシデロホアであるムギネ酸に 


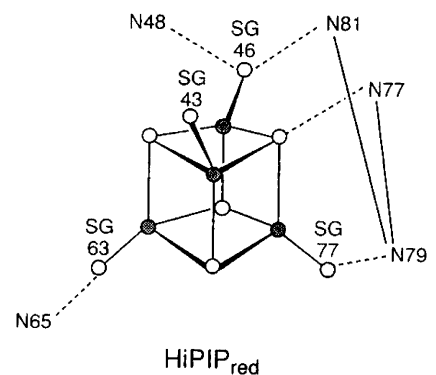

Fig. 23. Schematic Drawing of $\mathrm{Fe}_{4} \mathrm{~S}_{4}$ Cluster in Reduced Chromatium vinosum

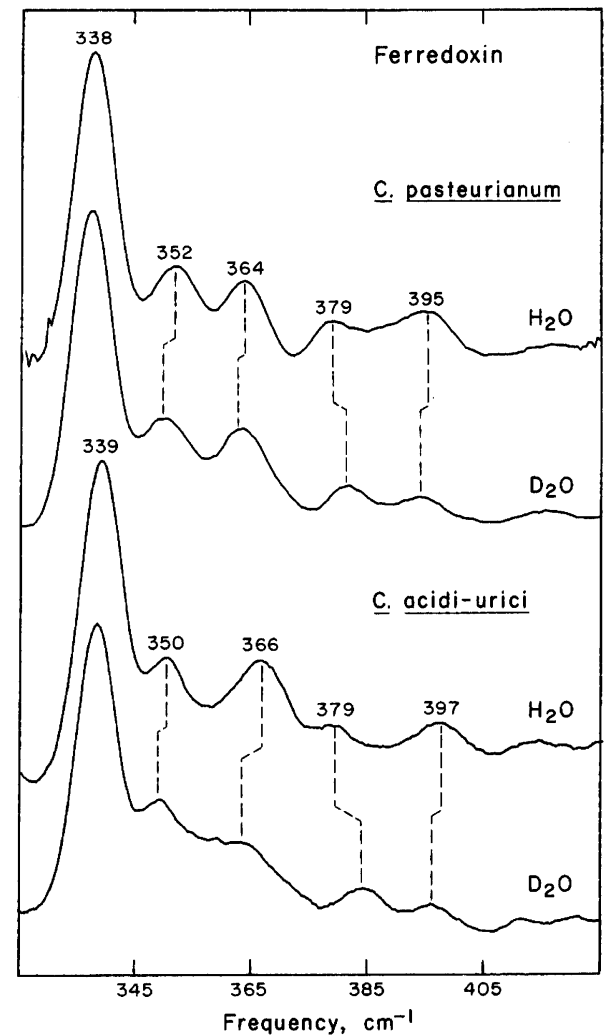

Fig. 24. Resonance Raman Spectra of Oxidized Ferredoxins from Clostridium pasteurianum and Clostridium acidi-urici in $\mathrm{H}_{2} \mathrm{O}$ and $\mathrm{D}_{2} \mathrm{O}$

ついても，ヒトあるいは哺乳動物に対してどのよう な生理活性を持つか, 今後の研究が大いに期待され る.なお，ムギネ酸の鉄排泄剂としての活性に関し ては筆者の報告を参照されたい. ${ }^{19)}$

3. マンガンペルオキシダーゼの構造とダイオキ シンの分解

生体に取り込まれた鉄は様々な構造の分子として 存在し，多彩な機能を果たしている。ここでは，へ ムタンパク質の一種ペルオキシダーゼを取り上げた.

製紙工業において，木材に多量に含まれるリグニ

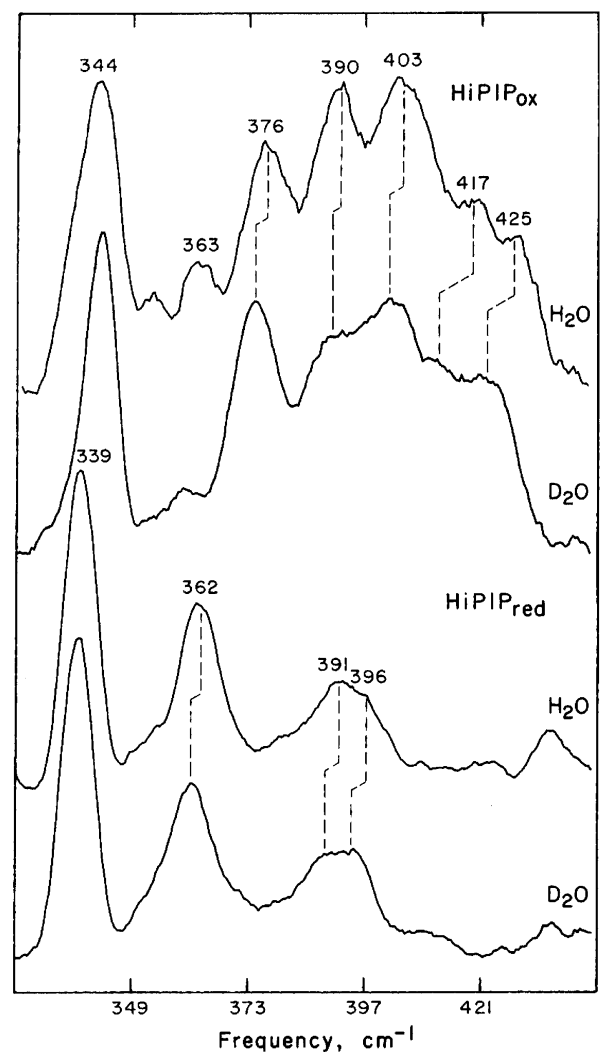

Fig. 25. Resonance Raman Spectra of Oxidized and Reduced Chromatium vinosum $\mathrm{HiPIP}$ in $\mathrm{H}_{2} \mathrm{O}$ and $\mathrm{D}_{2} \mathrm{O}$

ンは厄介ものであり，その分解法の開発が望まれて いる，興味深いことに，細菌でさえ難しいこの分解 をキノコの一種（白色腐朽菌）はなし遂げることが できる. Oregon Graduate Center に留学中，私は キノコ (Phanerochaete chrysosporium) の分泌す るリグニン分解酵素の一種, マンガンペルオキシ ダーゼ (manganese peroxidase; MnP) の構造解析 を行う機会を得た。共鳴ラマン分光法と ESR で検 討した結果，その活性中心は高スピン型の Fe（III） を含むへムで，5番目の配位子として His が結合し ており，HRP， シトクロムcペルオキシダーゼ,

リグニンペルオキシダーゼの活性中心と類似の構造 であることを明らかにした (Figs. 15 and 16). 20) す なわち, へムの配位環境を反映する共鳴ラマンスペ クトルの比較から, MnP とこれらのへムタンパク 質の活性中心の類似性を明らかにし， ${ }^{14} \mathrm{NO}$ あるい は ${ }^{15} \mathrm{NO}$ 付加体の ESR スペクトルの比較から His の配位を確認した。 またこの研究をヒントに，身近 な白色腐朽菌によるダイオキシンなど難分解性污染 物質の分解法及び $\mathrm{Fe}^{3+}-\mathrm{H}_{2} \mathrm{O}_{2}$ の混合試薬による環 境污染物質の分解法などを開発している. ${ }^{21-28)}$ すな 

(1) Ephedra sinica I I
(2) Ephedra sinica II $\$$
(3) Ephedra foliata
(4) Ephedra intermedia £
(5) Ephedra americana
(6) Atropa bel/adonna
(7) Hyoscyamus niger
(8) Solanum nigrum
(9) Solanum /yratum
(10) Solanum indicum
(11) Solanum abutiloides
(12) Scopolia japonica
(13) Lycium chinense
(14) Capsicum annuum
(15) Nicotiana tabacum
(16) Physalis alkekengi*
(17) Datura stramonium $\dagger$
(18) Datura mete/ $\neq$
(19) Datura arborea
(20) Pueraria lobata
(21) Leucaena g/auca
(22) Medicago sativa
(23) Pisum sativum
(24) Trifolium pratense
(25) Brassica napus
(26) Panax ginseng
(27) Petrose/inum sativum
(28) Phytolacca americana
(29) Phytolacca esculenta
(30) Spinacia oleracea
(31) Sambucus nigra
(32) Arctium lappa
(33) Colocasia esculenta
(34) Triticum aestivum
(35) Hordeum vulgare
(36) Oryza sativa
(37) Equisetum telmateia
(38) Equisetum arvense
(39) Gleichenia japonica

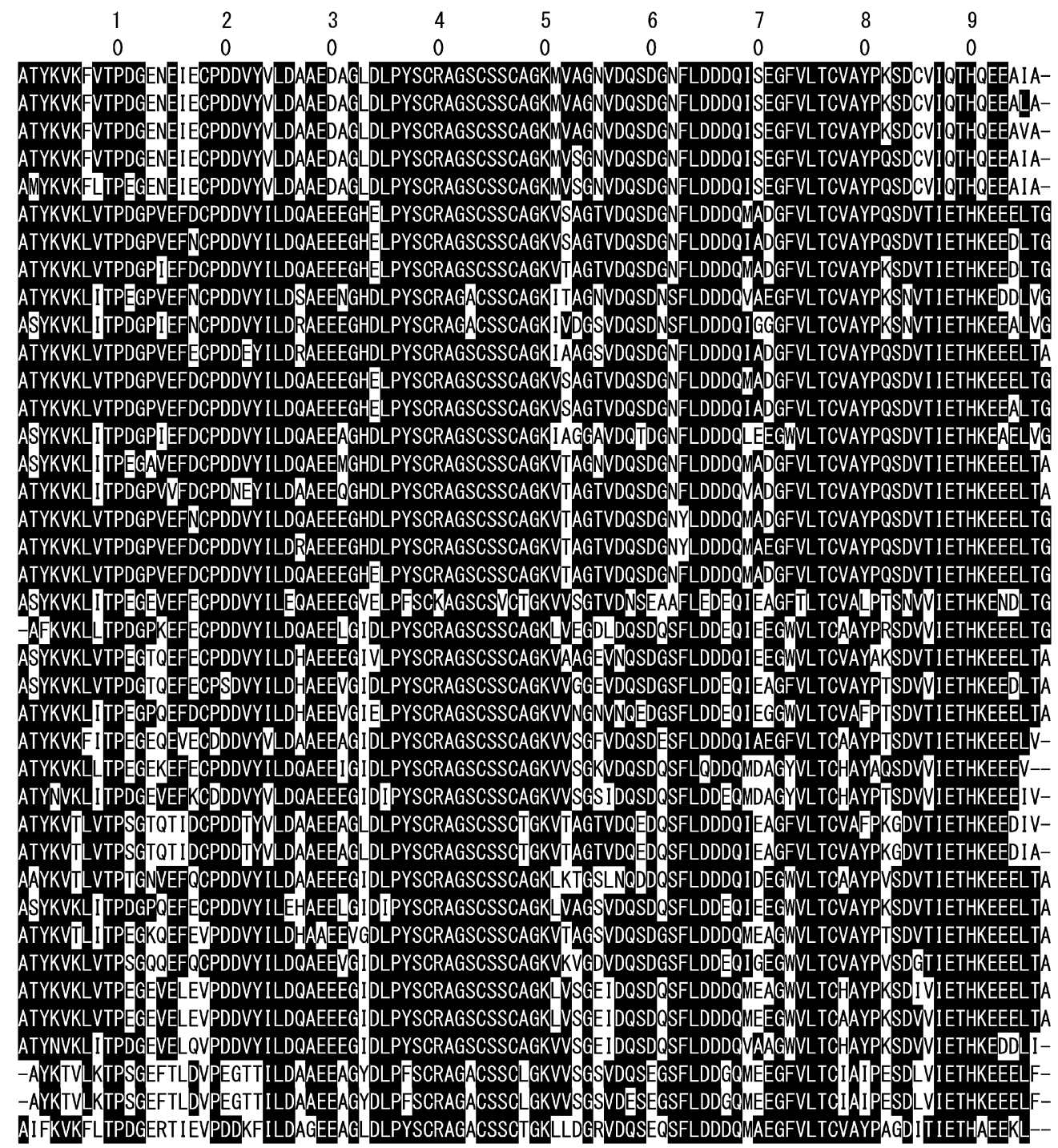

Fig. 26. Comparison of the Sequences of $[2 \mathrm{Fe}-2 \mathrm{~S}]$ Ferredoxins from Higher Plants

Amino acids are represented by one-letter abbreviations. "Ephedra distachya I, Ephedra equisetina I, Ephedra viridis, and Ephedra intermedia; ${ }^{\$}$ Ephedra distachy $\mathrm{II}$ and Ephedra equisetina II; ${ }^{\circledR}$ minor Fd from Ephedra intermedia; ${ }^{*}$ Physalis alkekengi var. francheti; ${ }^{\dagger}$ var. stramonium and var. tatula, and Datura quercifolia, ${ }^{\ddagger}$ Datura metel, Datura innoxia, and Datura fastuosa.

わち，食用キノコ菌でもダイオキシンをわずかなが ら分解できること, また，安価な $\mathrm{Fe}^{3+}-\mathrm{H}_{2} \mathrm{O}_{2}$ の混 合試薬がダイオキシン分解に有効であることなどを 明らかにした (Fig. 17).

4. 共鳴ラマン分光法による鉄硫黄タンパク質中 の水素結合の検出とその重要性

代表的なブルー銅タンパク質と鉄硫黄タンパク質 のラマンスペクトルにおいて同程度の重水素同位体 シフトを観察したことから，ブルー銅タンパク質に おけるシフトがイミダゾール窒素（His）の水素原 子ではなく, 硫黄配位子に水素結合している $\mathrm{OH}$ （Ser）やアミドの水素原子に起因することを明らか

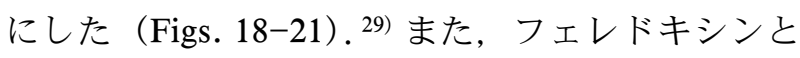

高電位鉄硫黄タンパク質（HiPIP） の $\mathrm{Fe}_{4} \mathrm{~S}_{4}$ クラス ター構造の違いを共鳴ラマン分光法と $\mathrm{X}$ 線結晶解 析により明らかにした (Figs. 22-25).30)

5. 植物フェレドキシンの一次構造を用いる植物 の化学分類学

植物フェレドキシンは光合成の電子伝達系に深く 関与し，すべての植物に含まれる鉄硫黄タンパク質 である.このタンパク質の一次構造を解析すること で植物の類縁関係を考察し，また，これを利用して 重要な植物の化学的同定法の開発を目指してきた.

なお, 詳細な一次構造の比較から, ナス科に特徵的 な配列（例えば，33 番目のアミノ酸はヒスチジン） や各属（species）に特徵的な配列も明らかにした 


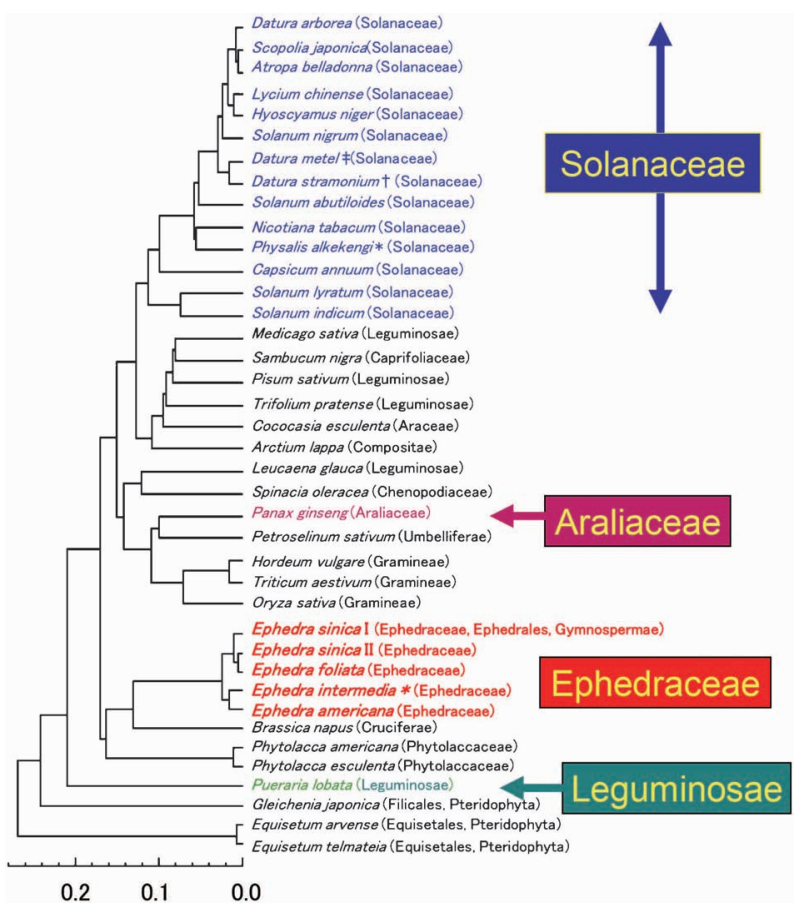

Fig. 27. Phylogenetic Tree Based on the Amino Acid Sequences of Ferredoxins from Higher Plants

The phylogenetic tree was constructed using the UPGMA method of Saitou and Nei (1987) (GENETYX software). Genetic distances are represented by the proportion of amino acid differences between each taxon $(1.0=100 \%)$.
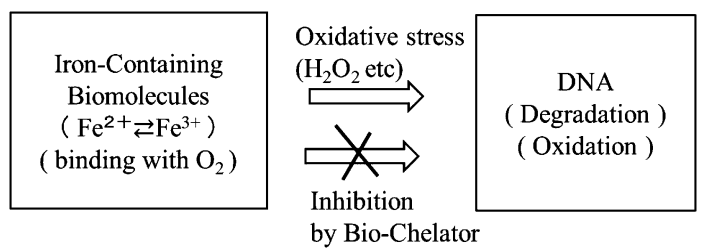

Fig. 28. Effect of Iron-containing Biomolecules on DNA

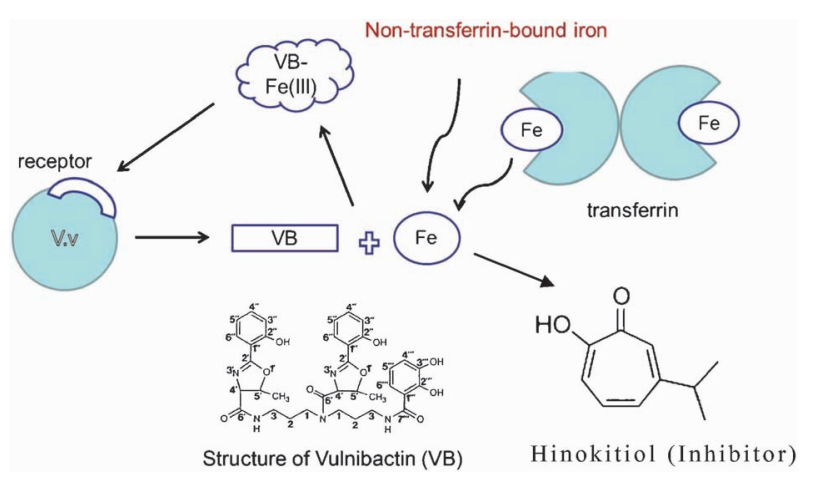

Fig. 29. Biological Iron Transport System in Vibrio vulnificus (V.v) and the Structures of Vulnibactin ( $V . v$ Siderophore) and Hinokitiol (Inhibitor)

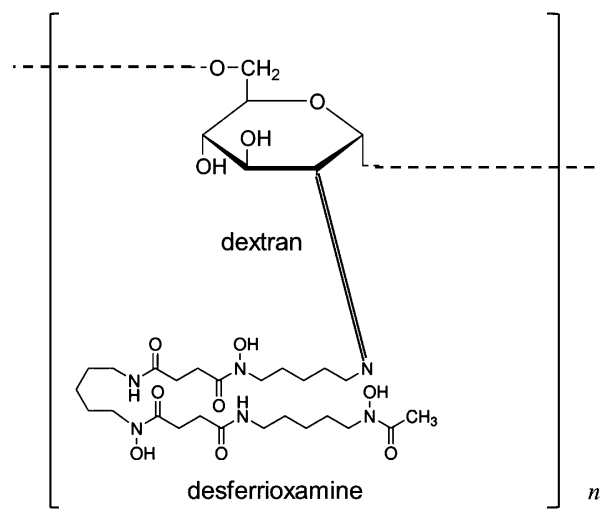

Fig. 30. The Possible Structure of Desferrioxamine-Dextran Hybrid

(Figs. 26 and 27). ${ }^{31-45)}$

\section{6. 鉄含有生体分子のDNA に及ぼす影響}

鉄を含有する生体分子には多彩な機能を有するも のが多い.これは，鉄原子の酸化還元作用や酸素原 子との親和性に主に起因している。このような反応 性を有する鉄含有分子が核酸の構造になんらかの影 響を及ぼすことは十分に考えられる（Fig. 28）。そ こで，代表的な鉄含有生体分子が DNA の構造に及 ぼす影響について検討した。その結果，(1)数種の鉄 含有タンパク質は, $\mathrm{H}_{2} \mathrm{O}_{2}(26 \mu \mathrm{M}-260 \mathrm{mM})$ 存在下, DNA の分解を引き起こす, (2)カタラーゼとペルオ キシダーゼにはそのような分解活性は認められない, (3)鉄含有生体分子の DNA 分解活性は, 強力なキ レート剤の共存で抑制される,などの知見を得た. ${ }^{46)}$

生体中の $\mathrm{H}_{2} \mathrm{O}_{2}$ 濃度レベルで, 鉄含有生体分子に よる DNA 分解が起これば，生体に少なからず障害 をもたらすと推測される。この点に関して，DFな どの鉄キレーターが DNA 分解活性を抑制する事実 は, 生体内で有効なキレーター（bio-chelator と呼 ぶ）の医薬品としての可能性を示唆するものであ り，興味深い。また，鉄含有生体分子の DNA に対 する酸化ストレス作用についても，今後，検討され るべきである.

\section{7. 微生物の鉄獲得系に作用する新規抗菌剂の開} 発

微生物は，鉄欠乏状態において菌体外にシデロホ アを分泌し，錯形成により不溶性の鉄を溶かし，そ の鉄錯体を菌体膜のレセプターを介して体内に取り 込むことで増殖する。このように微生物はシデロホ アの関与する優れた鉄獲得系を有している，病原菌 
もまた宿主の体の中で鉄を利用して増殖する，生体 の中の鉄分はへモグロビンやトランスフェリン, フェリチンの形で強固に結合しており，簡単に細菌 に鉄を奪われることは少ないが，強力なシデロホア を分泌する病原菌はそれらの鉄を奪って増殖する。 その結果，宿主である人は敗血症などの重篤な病気 を引き起こす。この病原菌の鉄獲得系を阻害するこ とで新規な抗菌剤の開発が可能である（Fig. 29）. 例えば，病原菌のシデロホアより強力な鉄キレート 剤と競合させることで，病原菌の増殖を抑制するこ とが期待できる，そこで，筆者は人食いバクテリア の一種, Vibrio vulnificus の鉄獲得系を阻害するこ とでその増殖を抑制する新たな抗菌剤の開発を検討 した。この病原菌はバルニバクチンと呼ばれる強力 なシデロホアを分泌して，鉄を取り込んでおり，バ ルニバクチンより強力な鉄キレーターにはその増殖 阻害活性が期待できる。そこで，多くの市販のキ レート剤を始め，種々のシデロホアなど天然のキ レート剂について，V.vulnificusにおける増殖阻害 活性を調べたところ，ヒノキチオールに極めて高い 阻害活性があることを突き止めた。 ${ }^{47)}$ すなわち， ヒ ノキチオールは $1 \times 10^{-5} \mathrm{M}$ でほぼ完全にこの菌の増 殖を抑制した。その活性の程度は，強い増殖阻害活 性を有することで著名な ethylenediamine- $N, N^{\prime}$-bis （2-hydroxyphenylacetic acid）（EDDHA）の活性 （同じ濃度で約 $30 \%$ 抑制）より明らかに強かった。 ヒノキチオール分子のトロポロン骨格が鉄との結合 に関与していると推定できる。 また，鉄との親和性 が比較的強い DF に増殖阻害活性が認められなかつ たことから，V.vulnificus は，この鉄錯体自体を取 り込み利用することが可能であると推測された。 そ こで，取り込まれ難くするため，DF-デキストリン のハイブリッド体を合成し，その活性を調べてい る。なお，ハイブリッド体は，まず， $\mathrm{NaIO}_{4}$ 酸化 でデキストランの水酸基をカルボニル基に変換後,

DF 分子のアミノ基との間でシッフ塩基を形成する ことで比較的容易に合成することが可能である (Fig. 30)。このハイブリッド体では，多糖と結合 することで DF 自体の毒性が極端に軽減させること が報告されており，大量投与できるメリットもある と考えられる. ${ }^{48)}$ さらに, 血液中で分解され難いイ ヌリンとのハイブリッド体も興味ある化合物であ り，その活性についても現在調査中である。これら
の化合物は, $V$. vulnificus 感染による敗血症を抑え る効果が期待できる.

おわりに

鉄は必須金属であるが，過剩の鉄は体内の臓器な どに沈着し，フェントン反応を介して活性酸素種を 生じさせ，これらが様々な病気の原因になることが 知られている。特に，トランスフェリンと結合して いない non transferrin-bound iron（生体不安定鉄） の，毒作用における重要性が最近指摘されてい

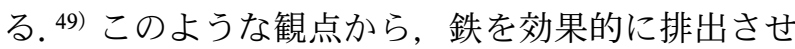
るキレート剤（bio-chelator）は新しいタイプの医 薬品として有用であろう。日本の男女の平均寿命は 約 6 歳の差がある。いかなる理由でその差が現れる のか，現在のところ不明であるが，女性の場合は鉄 欠乏気味であることを考えると，男性と比べ鉄の毒 作用の影響を受け難いことも確かである，男女の平 均寿命の差と鉄との関係も今後明らかになっていく と思われる. 今後, 鉄に関する多彩な研究が精力的 に進められることを期待したい.

利益相反＼cjkstart開示すべき利益相反はない.

\section{REFERENCES}

1) Raymond K. N., Carrano C. J., Acc. Chem. Res., 12, 183-190 (1979).

2) Neilands J. B., "Bioinorganic Chemistry-II," ed. by Raymond K. N., American Chemical Society, Washington, DC, 1977, pp. 3-32.

3) Snow G. A., Bacteriol. Rev., 34, 99-125 (1970).

4) Neilands J. B., Erickson T. J., Rastetter W. H., J. Biol. Chem., 256, 3831-3832 (1981).

5) Tufano T. P., Raymond K. N., J. Am. Chem. Soc., 103, 6617-6624 (1981).

6) Brown J. C., "Bioinorganic Chemistry-II," ed. by Raymond K. N., American Chemical Society, Washinton, DC., 1977, pp. 93-103.

7) Takagi S., Soil Sci. Plant Nutr., 22, 423-433 (1976).

8) Takemoto T., Nomoto K., Fushiya S., Ouchi R., Kusano G., Hikino H., Takagi S., Matsuura Y., Kakudo M., Proc. Japan Acad., 54, 469-473 (1978).

9) Fushiya S., Sato Y., Nozoe S., Nomoto K., Takemoto T., Takagi S., Tetrahedron Lett., 
21, 3071-3072 (1980) .

10) Nomoto K., Mino Y., Ishida T., Yoshioka H., Ota N., Inoue M., Takagi S., Takemoto T., $J$. Chem. Soc. Chem. Commun., 338-339 (1981).

11) Mino Y., Ishida T., Ota N., Inoue M., Nomoto K., Yoshioka H., Takemoto T., Sugiura Y., Tanaka H., Inorg. Chem., 20, 3440-3444 (1981).

12) Sugiura Y., Tanaka H., Mino Y., Ishida T., Ota N., Inoue M., Nomoto K., Yoshioka H., Takemoto T., J. Am. Chem. Soc., 103, 69796982 (1981).

13) Mino $Y$. , Ishida $T$, Ota N., Inoue M., Nomoto K., Takemoto T., Tanaka H., Sugiura Y., $J$. Am. Chem. Soc., 105, 4671-4676 (1983).

14) Iwashita T., Mino Y., Naoki H., Sugiura Y., Nomoto K., Biochemistry, 22, 4842-4845 (1983).

15) Sugiura Y., Mino Y., Iwashita T., Nomoto K., J. Am. Chem. Soc., 107, 4667-4669 (1985).

16) Oida F., Ota N., Mino Y., Nomoto K., Sugiura Y., J. Am. Chem. Soc., 111, 34363437 (1989).

17) Mino Y., Bull. Osaka Univ. Pharm. Sci., 1, 119-124 (2007).

18) Takahashi M., Nakanishi H., Kawasaki S., Nishizawa N. K., Mori S., Nat. Biotechnol., 19, 466-469 (2001).

19) Mino Y., Inoshiri S., Uchida K., Ujita K., Yasuda M., Bull. Osaka Univ. Pharm. Sci., 1, 113-117 (2007).

20) Mino Y., Wariishi H., Blackburn N. J., Loehr T. M., Gold M. H., J. Biol. Chem., 263, 7029-7036 (1989)

21) Mino Y., Tokusan Joho, 20, 58-59 (1999).

22) NIHON KEIZAI Newspaper, March 20, 1999.

23) MAINICHI Newspaper, March 31, 1999.

24) NIKKEI ECO21, 9, 28-29 (1999).

25) Mino Y., Moriyama Y., Chem. Pharm. Bull., 49, 1050-1051 (2001).

26) Mino Y., Moriyama Y., Nakatake Y., Chemosphere, 57, 365-372 (2004).

27) Azuma T., Mino Y., J. Health Sci., 57, 442447 (2011).

28) Azuma T., Mino Y., Environment \& Sanitary Engineering Research, 25, 14-21 (2011).

29) Mino Y., Loehr T. M., Wada K., Matsubara H., Sanders-Loehr J., Biochemistry, 26, 8059-
8065 (1987).

30) Backes G., Mino Y., Loehr T. M., Meyer T. E., Cusanovich M. A., Sweeney W. V., Adman E. T., Sanders-Loehr J., J. Am. Chem. Soc., 113, 2055-2064 (1991).

31) Mino Y., Chem. Pharm. Bull., 39, 1585-1587 (1991).

32) Mino Y., Usami H., Inoue S., Ikeda K., Ota N., Phytochemistry, 33, 601-605 (1993) .

33) Mino Y., Phytochemistry, 35, 385-387 (1994).

34) Mino Y., Phytochemistry, 37, 429-431 (1994).

35) Mino Y., Chem. Pharm. Bull., 43, 1186-1189 (1995).

36) Mino Y., Yasuda K., Phytochemistry, 49, 1631-1636 (1998).

37) Mino Y., Iwao M., Biol. Pharm, Bull., 22, 9699 (1999).

38) Mino Y., Iwao M., Natural Med., 53, 37-41 (1999).

39) Mino Y., Biol. Pharm. Bull., 25, 1367-1369 (2002).

40) Mino Y., Hazama T., Machida Y., Phytochemistry, 62, 657-662 (2003).

41) Mino Y., Shirakawa M., Harada Y., Kuroda K., Biol. Pharm. Bull., 27, 2038-2041 (2004).

42) Mino Y., Yukita M., Hiratsuka N., Wariishi H., Biol. Pharm. Bull., 28, 1535-1538 (2005).

43) Mino Y., Machida Y., Wariishi H., Natural Med., 59, 181-185 (2005).

44) Mino Y., Biol. Pharm. Bull., 29, 1771-1774 (2006) .

45) Mino Y., Azuma T, Sato T., Bull. Osaka Univ. Pharm. Sci., 9, 53-60 (2015).

46) Mino Y., High Tech. Research Center Research Projects (Osaka University of Pharmaceutical Sciences), 2007-2009 Research Reports, 2010, pp. 145-150.

47) Mino Y., High Tech. Research Center (Osaka University of Pharmaceutical Sciences), 2015 Symposium Abstract, December 5, 2015, pp. 7-8.

48) Hallaway P. E., Eaton J. W., Panter S. S., Hedlund B. E., Proc. Natl. Acad. Sci. USA, 86, 10108-10112 (1989).

49) Brissot P., Ropert M., Le Lan C., Loréal O., Biochim. Biophys. Acta, 1820, 403-410 (2012). 